\title{
Jade Mythological Genes and Chinese Cultural Identity
}

\author{
Juan Wu \\ School of Foreign Language, Beijing Institute of Technology, China
}

\begin{abstract}
This paper, focus on a critical cultural heritage and long-ignored cultural phenomena, Chinese jade mythology, to explore the core values that accompanies the formation of Chinese civilization and explain how they function as the material and spiritual bonding in the formation of Chinese identity and continuation of Chinese civilization. By identifying the centripetal force of jade, the structure of the multi-cultures and the integrated civilization of Central Plains and the formation mechanism of Chinese culture could be revealed.
\end{abstract}

Keywords: Gold Worship, Jade Virtue, Jade Mythology, Cultural Identity.

Max Weber believed that social science, unlike the natural science that explores the universal rules of things, but explores the values of specific culture and the cultural phenomena of social reality dominated by these values. Since the cultural phenomena are complex and blurring at times, it is essential to distinguish the important from the trivial and identify the underlying driving force and the most central values of certain cultural system. Weber suggests that, "All knowledge of cultural reality, as may be seen, is always knowledge from particular points of view. When we require from the historian and social research worker as an elementary presumption that they distinguish the important from the trivial and that he should have the necessary 'point of view' for this distinction, we mean that they must understand how to relate the events of the real world consciously or unconsciously to universal 'cultural values' and to select out those relationships which are significant for us." (Weber, 1949: 81) Inspired by this suggestion, this paper, focus on a long-ignored cultural phenomena, Chinese jade mythology, to explore the core values that accompanies the formation of Chinese civilization and explain how they function as the material and spiritual bonding in the formation of Chinese identity and continuation of Chinese civilization. By identifying the centripetal force of jade, the structure of the multi-cultures and the integrated civilization of Central Plains and the formation mechanism of Chinese culture could be revealed.

\section{THE GOLDEN BOUGH AND WORSHIP OF GOLD}

Cultural identity is formed and fortify by a combination of linguistic, economic, religious, or conventional factors, yet according to Selim Abou cultural identity "fundamentally refers to ethnicity. "It characterizes a group whose members claim a common history or origin and a specific cultural heritage, no matter that the history or origin is often mythicized or that the cultural legacy is never totally homogeneous. The essential thing is that these common elements are lived by the concerned group as distinctive characteristics and perceived as such by others." (Abou, 2008:11) In other words, the core element of cultural identity lies in the certain mythicized history or shared cultural heritage. When the mythicized cultural heritage is shared by a nation that is consists of many ethnics, then cultural identity extends form the ethnic level to the national scope.

Magic treasures appear in almost all mythological narrations relating to the ancient heroes or kings. A 12-volume masterpiece The Golden Bough (Frazer, 1987) comes out at the turn of 19th and 20th century and exerts tremendous influence on the following writers, including T. S. Eliot and James Joyce. Since bough made from gold does not exist in reality, it is the mythological association and literary imagination that connects the metal of gold and the plant of bough. In Chapter One of the $1^{\text {st }}$ edition of The Golden Bough, the mythical narrative of Diana, the Goddess of Nemi Lake, worshiped as "the King of the Wood" is introduced with great details. Within Diana's temple grew a special tree, protected by the priest, no branch of which might be broken. Only a runaway slave was allowed to 
break off, if he could, one of its boughs. Success in the attempt entitled him to fight the priest in single combat, and if he slew him he reigned in his stead with the title of King of the Wood. According to the public opinion of the ancients the fateful branch was the Golden Bough which, at Sibyl's bidding, Aeneas plucked before he essayed the perilous journey to the world of dead. (Frazer, 1955: 11)

From the story, we know that the golden bough, as a mysterious magic weapon, originally belongs to the goddess of the world of the dead, not to the secular world. Mythological imagination gives the plucked bough the capacity to independently grow, which implies the magic rebirth power of life. Immortality is the basic theme and common motif of all prehistoric mythological belief systems, which is inherited in the form of literature and combined with the metal myths since the Bronze Age. (Frazer, 1922: 3-22) As a rare metal massively mined with the coming of civilization, gold became a sign of holiness and immortality. Alchemy, which integrated the longing for immortality in prehistoric myths and the desire for gold in civilized society, became an active and continuous practice. Plants in reality have their birth and death, and their lives are not characterized with the annual circulation of flourishing and decaying. However, the golden bough and leaf in Roman mythology goes beyond the boundary of birth and death, becoming the magic light that directs and light up the way of the world of the dead.

The internal connection between gold and godhood in Roman mythology is essential to comprehend the underlying message within the story. At the beginning of Book VI of the Aeneid, Diana's temple is referred to as "being roofed with gold" (Virgil, 1983: 159) Zeus, the supreme god of the ancient Greeks, once turned into the gold rain to date the princess Danae. In The Theogony, Hesiod referred Hera, the Queen of Heaven, as "the goddess in golden shoes" (Hesiod, 1991: 27) and when referring to other gods, he also used "Hebe who wears gold crown", "Pheobe in gold crown" etc. (Hesiod, 1991: 30) At first, gold was holy material that belonged to the deities. Under Virgil's pen, the golden bough grew on a tree with golden leaves, which, besides showing a golden color, gave away a clanking sound. The semi-god hero found this treasure under the guidance of a pair of doves. This detail shows that the golden bough was the holy gift from the deities, which was beyond ordinary people's reach. Since dove, in Christian myths, is the symbol of the Holy Spirit. (Gaskell, 1989: 229230).According to New Testament, in Gospel of Saint John, John testified that "I saw the Holy Spirit, coming down from the heaven like a dove, and resting on Him." (New Testament: Gospel of Saint John. Chapter One, Article 32-33).In western mythological belief, dove is the medium connecting man and god, which is obvious in this story. The intimacy of Roman ancestors and holy articles leads to a narrative mode dominated by mythological concepts: certain king or hero, under the direction of a medium that conveyed god's will, obtained certain symbolic holy article or treasure, which beyond the limitation and capability of ordinary people.

The theme of magic treasure, whether it is the golden apple, the Golden Fleece, Aladdin's lamp, or the calabash containing secrets, even the magic stone, the tree satisfying wishes or the magic ring, is essential to all nations' narrative literature. It is difficult to explaining the causality between prehistoric gold mythology and gold, in other words, concept and material which one comes the first. If there is no gold, there will be no gold worship. In this sense, material determines concept. Conversely, where there is no worship for gold, people won't start mining gold. In this sense, concept determine actions. We could assure that the "god is holy" concept was no literary incident, but an outcome of combination of social, group belief.

\section{Chinese Jade Age ANd Worship of JADE}

As the luster and color of gold obsessed the Greek and Roman writers, the beautiful jades, jade cream and jade flowers obsessed those Chinese writers. (Bernstein, 2008: 1-6) In the eyes of western, the eternal tree of life might be shining and glimmering as gold, while in the eyes of Chinese, it might be as green and gentle as the jades. The reason why Chinese value and worship not only gold, but also jade, is that Chinese civilization has for several-thousand-year experienced a "Jade Age" right from the beginning of its formation. Gold has had a history of around 3000 to 4000 years, while jade of around 7000 to 8000 years, twice that of gold. (Liu Jinhua, 2007: 26) Though the economic value of some other natural resources, such as gold, silver, bronze and iron, are emphasized as well in these narratives, none of them could compete with jade in the way that it closely connected to the origin of Chinese civilization and the essence of Chinese virtue. 
Chinese history mythology which has lasted for 8000 years, from the early jade articles created by ancient people in Xinglongwa Culture that manifests their worship and appreciation for jades to Cao Xueqin's jade-related novel A Dream in Red Mansions. In China, since the medieval times, pictures narrating that the Northern tribes contributed treasures to the emperor have been common in jade carvings, which entrusted the foreign tribes with the task of bringing rare treasures. Jade, as a natural mineral, enjoy certain characteristics that are superior to other minerals. Firstly, it's formed in extremely harsh conditions, which makes it rare and special. Secondly, it has special physical properties, such as, the hardness, color and luster, and the touch. Numerous phrases and idioms in Book of Odes, including "a gentleman is as gentle as jade", "a gentleman always wear jade", a gentleman shall cultivate his morals the way jade is sculpted - by "cutting, polishing, carving and rubbing" and many Chinese idioms, like "rather die for jade than live for tiles" or "change shields and daggers to jade objects and silk fabrics. According to Ye Shuxian, all these jade virtues which related to jade's physical properties are the reflection of the great tradition of "jade-as-god". And the reason why jade is respected in the little tradition of Chinese civilization lies in the jade myths of 5000 years ago. Jade myths are particular to Chinese mythology, and the mythological mode of thoughts provide a multi-dimensional panoramic view of the origin of Chinese civilization.

In order to grasp the archeology of Chinese civilization core value that implies in the jade, the fundamental work shall be centered on the spiritual and conceptual analysis of jade, that is the core of jade myths. It is should be note that in May, 2013, at the international symposium on literary anthropology held at the Shaanxi Normal University, Chinese comparative mythologists borrowed and adopted a pair of western anthropological terms, the "Little Tradition" (the folk/unlettered) and the "Great Tradition" (the elites/literate), which were coined by Milton Singer and Robert Redifield when they studied the orthogenesis of Indian Civilization in Madras city. In their view, "Great Tradition" is a body of knowledge which functions as the beacon light of knowledge and associated with the elites, literate and reflective few who are capable of analyzing, interpreting and reflecting cultural knowledge. In contradiction, "Little Tradition" comprises the belief pattern, the institutions, including proverbs, riddles, anecdotes, folk tales, legends, myths or unlettered peasants who imbibe cultural knowledge from the great tradition. Cultural performance are institutionalized around the structure of both great tradition and little tradition. Ye Shuxian redefines the "Little Tradition" as the cultural tradition marked by metal and language characters and the "Great Tradition" as the cultural tradition before the appearance of characters, metals and nations (Ye Shuxian, 2011: 8). On the basis of this redefinition of tradition, Ye Shuxian exams the cultural tradition marked by metal and Chinese characters, and the cultural tradition before the appearance of characters, metals and nations and to reinterpret the cultural genes and cultural encoding of the little tradition, and identify the origin and characteristics of the formation of Chinese nationality.

Ye's study of jade is interpreted on the mystical witchcraft and magic in the comparative religious studies. Chinese jade, together with the western "hierophany" — gold and Lapis Lazuli, enjoys a holy and sublime status in the early civilization. The earliest "jade as god" appears in the great tradition of mythological world. In The Golden Bough and the Jade Leaf (Ye Shuxian, 2012), Ye Shuxian analyzes six jade mythological narratives - Yellow Emperor plants jade, etc. - that starts from "the legendary Chinese ancestor Yellow Emperor and ends with the three wise rulers of Xia, Shang and Zhou dynasties." (Ye Shuxian, 2012: 23) to "interprete the little tradition of characters by the knowledge of great tradition" (Ye Shuxian, 2012: 13), and verify the great tradition by the little tradition. According to the division of great tradition and little tradition, Ye Shuxian arranges Chinese prehistoric mythology into three cultural levels: pre-Yangshao Culture (worship for jade god - jade pieces and Huang), Yangshao Culture age, (the incubation period of jade mythology - jade lock, Huang, and Bi), Long Shang Culture age (formative period of jade mythology - Qiong, Zhang, and Gui).

Another example is Xu's studies on the national sacrifices by connecting the sacrifice system with the unearthed prehistoric rites and places. Xu Daoyun points out there are two sacrifice systems - Jiao Ti (a sacrifice to the gods, held by the witches on the hillock in the royal animal park, with the vessel of sacrificial jade) and $\mathrm{Zu}$ Zong (a sacrifice to the ancestors, held by the descendants in the ancestral temple of a ruling house, with the sacrificial vessel of daily vibrant). According to this category, Hongshan Culture and Liangzhe Culture belongs to be Jiao Ti honoring the gods, while those in Yangshao belongs to be $\mathrm{Zu}$ Zong honoring the ancestors. The combination of two sacrifice systems 
could be found in Rangfentao Temple; the Shang people honored their ancestors before honoring the gods, which was the summit of ancestor worshiping; the Zhou people worshiped both the gods and the ancestor, combing Jiao Ti and Zu Zong; till the Ming and Qing dynasties, Tai Miao (the Imperial Ancestral Temple) and Tian Tan (Temple of Heaven), Di Tan (Temple of Earth) still co-existed. (Xu Daoyun, 2002: 18) To category the sacrifice to gods and ancestors still remains to be further discussed, Xu's multi-discipline approach provides him with a capability to get beyond the limitation of written narrative and grasp the inheritance of jade spirit in Chinese rites.

\section{JADE-AS-God: JADE MYThical NarRatives ANd Holy Sublimity}

In The Classic of Mountains and Seas, the Yellow Emperor, considered to be the Chinese national ancestor, planted jade flowers: Dan River came out of the Chen Mountain, and went west into the Cheng Pool. In the river grew many white jades. So did some jade cream whose origin was boiling. The Yellow Emperor fed on this cream and thus d black jades were produced. Watered by jade cream for five years, the Dan plant became colorless and smelled sweet. So the Yellow Emperor took jade flowers from the mountains and planted them on the southern side of the Zhong Mountain. Beautiful jades were pretty, solid and exquisite. With gentle luster, they shone lights and seemed soft. Since the ghosts and gods fed on jades, by wearing them, individuals could be protected from ominous things. (Yuan Ke, 1980: 41) Besides, the geographic area where the Yellow Emperor planted the jade flowers was described in detail: he had received the jade seeds from San Mountain and planted them to the south side of Zhong Mountain. "It was 460 li $(230 \mathrm{~km})$ from San Mountain to Zhong Mount." It is difficult to imagine how did Yellow Emperor covered such a far distance and how the local white jade cream of San Mountain gave birth to black jades, but what can be said is that jade in this story acquired a sacred value and broke the boundary between the real and the unreal.

In the jade narrative, the protagonist, the Yellow Emperor, is considered to be the ancestor of the Chinese, and it is worthwhile to examine this narrative carefully since it might deliver some subtle underlying core values of the Chinese civilization. First of all, he enjoyed the jade cream as a delicacy, then planted jade trees: he used the jade follower produced by the jade of the San Mountain as jade seeds, and planted them on the south side of Zhong Mountain. Thus was produced the best jade material which was called "Jin Yu Jade" (beautiful jade). Such jades were characterized as hard, dense and heavy, giving out gentle luster and appearing colorful like the original Dan Tree. Such characteristics and appearances of fine jades fully align with the jade virtues illustrated by Confucius, the connoted value of "overcoming the hard with the gentle" and the traditional custom of "a gentleman must wear jades". The jade planted by the Yellow Emperor acquired the same magic as the gold in the Western myths. The Classic of Mountains and Seas briefly refers to its two functions: first, being the delicacy enjoyed by the gods to increase their supernatural powers; second, being worn by gentlemen to protect them from evil and misfortune. These two functions of Chinese jades make them the bridge connecting humans and gods. This is meaningful since it exactly combines the origin of Chinese jade worship and jade culture with the 'holy' behavior the national ancestor, the Yellow Emperor, which in national Chinese memory is viewed as the genesis moment of Chinese civilization.

Here, jades explicitly become the secular bond between human and god and the holy medium to symbolize the communion between humans and gods. Since then, jades have become one of the most prevalent and important literary themes of countless poets and writers throughout the ages. As an example, one can point to the recreation of "jade cream". Guo Pu quoted from The Map of Rivers: "On the Shaoshi Mountain, there is white jade cream. Once having eaten the cream, man acquires the magic of immortality". In Song to the South Capital, Zhang Heng of the Han Dynasty said: "ganoderma lucidum grew in the houses, and jade cream filled all corners of the houses". Here, jade cream is put together with another magic and medical myth, that is ganoderma lucidum. In the first volume of the Encyclopedia of Nature, Zhang Hua of the Jin Dynasty said: "Among the famous mountains and rivers, inside the holes and caves, natural stone interacts and consequently gives birth to stone juice and jade cream. Eating them, man will not die." In the fourth poem of Reading the Classic of Mountains and Sea, Tao Yuanming, a famous Chinese pastoral poet in the Dongjing Dynasty, stated that, "Where the Dan Tree grows? On the south of Mi Mountain. Yellow flowers and red seeds. Eating them, life expands. White jade produces juices, beautiful jades shine magic lights. Aren't they a gentlemen's treasure? So much treasured by our Yellow Emperor". (Dai Qinlin, 1979: 135) 
Tao did not only love singing the story of the Yellow Emperor eating jade cream, but also imagined the jade cream as the juices from white jades, which inspired later generations' fantasy about jade juices. The previous writers, relating to the Yellow Emperor's jades, were following the observation of natural things to the core concept of immortality. These observations originated more from the prehistoric jade myths than from the creation of ancient men of letters, because the holy virtue of jade, representing supernatural godhood, magical changes and immortal lives, became through narratives over the centuries essential to the construction of Chinese culture.

In the Period of Warring states when The Classic of Mountains and Seas was written, gold had finished its millennium journey from the Western Regions to the Central Plains' civilization. (Ye Shuxian, 2009) In The Classic of Mountains and Seas, the most typical narrative mode is the resource reports of the mountain and rivers which emphasizes both the gold and jade. For example, in Classic of the Mountains: West, Zou Mountain is recorded as "there are no grass or trees on it. Qi River comes out of it and goes west into the sea. In the river, there are many colorful stones, gold and cinnabars". (Yuan Ke, 1980: 32) Shuli Mountain: "on the mountain, there is much gold. At its foot, there is much silver. Most of its trees are large and stark and most birds are parrots. Chu Rivus comes out of it and goes west into Wei River. In the river, there are many white jade balls." (Yuan Ke, 1980: 34) Longshou Mountain: "on the south side of the mountain is much gold and the north side iron. Tai Rivus comes out of it and goes southeast to Jing River. In the river, there are many beautiful jades". (Yuan Ke, 1980: 35) Zhongshou Mountain: "many jades dispersedly float on it. At its foot are many wingceltis and tangerines and gold. Most of its beasts have sharp horns." (Yuan Ke, 1980: 37) In such report mode which emphasize both metal and jade or stone resources, all gold, silver, bronze and iron are included, which have great economic values to human life. But none of them can compete with jade in the way it is closely connected to the ancestor of Chinese civilization and turns into magic articles.

Besides Yellow Emperor's planting jade, other myths listed by Ye show jade's sanctity and function of connecting man and god. To be specific: the story that a jade article made Yu the Great the ruler of the country, as recorded in Shang Shu and Records of the Grand Historian, shows jade's honorable status in secular world (Ye Shuxian, 2012: 16-17); Qi of Xia going up to heaven with the ring of jade in his right hand and semi-circular jade wearing around his waist shows that semi-circular jades and jade wearing are all holy media that connect man and god (Ye Shuxian, 2012: 19); according to The Yizhoushu, Zhou, the last emperor of Shang dynasty, burned himself together with jade, which implies that jade can be smelted (Ye Shuxian, 2012: 20); Jiang Ziya got semi-circular jade and the Duke of Zhou talked to the ancestors with jade sacrificial vessel, which shows that jade conveys mythical information (Ye Shuxian, 2012: 21) ; King Mu of Zhou visited the Yellow Emperor's Palace and got jade bough and jade leaf, which hints that the Yellow Emperor's Palace may be the palace where the worship of god with jades is performed (Ye Shuxian, 2012: 22). In the previous interpretation of mythological stories, Ye re-interpreted both the great and little tradition under the guide of the "jade-as-god" concept and presented the multi-dimensions of jade myths. With the aid of Charles de Brosses and F. M. Muller of comparative studies of religion, Ye confirmed the mythological association between "jade" and "god", points out that the tradition of regarding jade as god has potentially dominated the little tradition of "jade is virtue", and, more importantly, he suggests the method of searching for the driving force of regarding "jade as god", that is the "supernatural power" in myths (Ye Shuxian, 2012: 25).

\section{JAde as Treasure: Social INTEgRation OF MATERIAL WORSHIP AND FoRMATION OF Civilization}

How the magic weapon in literature came into being, the answer will go beyond the scope of literature and enter the territory of religion. If something is thought to have supernatural powers, it can be called "fetich" or "fetish". The idea that a deity can be various concrete and sensate object, which appears earlier than the abstract concept of god, was proposed by French thinker De Brussels. In Idol Worship for Gods or the Similarity between Ancient Egyptian Religion and the Living Negro Religion. Brussels intends to explore the origin of mythology and reveal the principles and rules hiding behind Greek mythology with the help of the nonwestern belief or uncivilized communities. As for the worshiping object, Brussels wrote: "the two parts of paganism are, either the worship for stars which we call as star worship, or worship for certain secular thing or material object, which we call as 'fetish' as what's 
among the African black people, as I call it- "shamanism". Although it original means the religion of black people, when I use it, it also refers to other nations' worship for the animals or lifeless objects. These things are deified, even when they are not deities, they already have the characteristics of deities, for example oracles, amulets, magic weapons etc. What can be sure is that, these though patterns share the same origin, which belongs to a common religion, which has long been spread over the whole world. It can only be explained by itself. Among various religions of the paganism world, it belongs to an independent type". (Max Müller, 1989: 40) Thanks to Brussels, the religious terms "fetish" and "shamanism" and a syllogistic pattern of "Shamanism - polytheism - monotheism" describing the human's religious development enjoy growing popularity in the academic circle

From the talk between Fenghuzi and King of Chu which had the judgment that "jade is also a deity", to Xu Shen's explanation of Ling (deity or god) as "the witches use jades to worship gods. Ling may be connected to witches", in the early stage of Chinese cultural history, the functions of jades basically conformed to the religious definition of shamanism. It helps us to understand why the jade worship of Chinese civilization differed from the western gold worship at the outset of the civilization. In other words, in the context of Chinese civilization, jade the holiness of jades was native, original and spontaneous, while the holiness of gold was derived after jades, and was more or less influenced by the foreign cultures, including the mining technologies and mythological concepts of metals.

In The Origin and Growth of Religion, a whole chapter (Chapter Two) devotes to discuss whether shamanism is the original form of religion or not. Müller studied the research works on shamanism during the almost 100 years since Brussels, and came to four key points: Firstly, the meaning of deity has been unclear and ambiguous since the start of its use, which has been widely used by most scholars, so it includes all symbolic or imitative images of objects worshiped in the religion. Secondly, In historical nations, almost all under the category of deities have there is historical and psychological causes. Thirdly, there is no religion which is totally unconnected to shamanism. Fourthly, there is no religion which is totally identical to shamanism. (Max Müller, 1989: 82) Müller admits shamanism has cross-culture commonality, but he disagrees to regard shamanism as the origin or primitive form of religion. He reminds people to look for the concept of superhuman power prior to the concrete object or material. Compared to superhuman power, fetish is merely the appearance derived from inner concepts. (Max Müller, 1989: 84)

According to Müller's suggestion, we need to further explore how the deities or superhuman powers infiltrated into the materials like jade, gold etc. By analogy to anthropologists' mythological concept of the deification of gold, the deification of jade can be interpreted like this: the color and luster of sky are the same as that of jade, so the sky is imagined as being made of jade. This is the base motive of taking jade as the symbolism of heaven, or the "De (virtues)". What needs to be analyzed is, during the Xia, Shang and Zhou dynasties, the concept of "De" was also a mythological concept, which was connected to the holy heaven's will. It was after the recreation of Confucianism that "De" evolved into a moral concept. For example, in the poem Xiao Yong, included in Classic of Peotry: Odes of Qin, "speaking of a gentleman, he shall be gentle as a jade"; in the notes written by Zheng Xuan, "jade has five virtues"; in his memorial to the throne, Kong Yingda cites from Etiquette in Appointing Officials, "a gentleman compares his virtues to the jade: jade is warm and humid, that means a gentleman shall have 'benevolence'; jade is fine and exquisite, that mans a gentleman shall have 'wisdom'; jade is clean but not discriminating, that means a gentleman shall have 'righteousness'; a hanging jade is like a drop, that means, a gentleman shall have 'propriety'; jade is trusted by the surroundings, that means, a gentleman shall have "trustworthiness"'. In Commentary to the Five Classics, the five virtues was explained differently: "jade have five virtues: jade is warm and humid, similar to 'wisdom'; jade is sharp but not harmful, similar to 'kindness', jade is suppressed but doesn't give in, similar to 'righteousness'; if jade has any flaw inside, the flaw will be shown, similar to 'trustworthiness'; a hanging jade is like a drop, similar to propriety".

The evolution from jade-as-god to jade-as-virtues was the outcome of the mythological concept transferred from the regime of religion to the morality, thus the notion of jade-as-virtue is inseparable from the mythological ideology of jade. Myth mythology is deeply rooted in Chinese civilization, whose role in constructing the Chinese identity cannot be undermined or underestimated. The formation of an integral national identity by integrating a large number of people with different living 
environment, languages and races on an immense geological area is a key factor that Chinese civilization can survive or even flourish for thousands of years. Kurimoto applied Browne's "the patterns of integration", which consist of "reciprocity", "redistribution" and "market exchange" to exam the formation of a large-scale social identity. Under the circumstances of reciprocity and redistribution, the social system which was formed under the patterns of integration is closely linked to the etiquette and religion. Thus these social systems plays the role of coordinating and integrating people's ways of socializing and consolidating the social structure. To some extent, the patterns of integration applied to almost all the social behaviors within the social and geological boundaries, rather than a mere set of concepts which mere confined to the economic scope. Therefore, the social borderlines could be identified as long as the reciprocity and the redistribution behaviors could be ascertained. (Shinichiro, 1997:49-50)

On the eve of the Bronze Age, jade plays an essential role in the construction and solidification of the spiritual authority in Chinese society. The integration of the former three patterns was accomplished during the interaction in trading jade resources from the local production places of jade to the Central Plains. After the coming of the Bronze Age, redistribution happened among the jade trading areas, adding the spatial distribution activities of new metals (gold, silver, copper, tin, lead etc.). Anthropologist Zhang Guangzhi holds that, Shang dynasty moved its capital for eight times, almost all of which were connected with the search for copper minerals. In Tale of King Mu, Son of Heaven, the King $\mathrm{Mu}$, during his travels to the west, established and strengthen commercial economic transaction with other tribes, which centered on the reciprocity of awarding jade articles or metal wares, or seeking jade materials etc. From this, we could see the demand of holy treasure (jade) which was infiltrated with mythological beliefs functioned as the basic or major motive to the economic and social integration of the Central Plains and the neighboring tribes. At the turning point to the civilization, we could see the holy treasure (jade) which was infiltrated with mythological beliefs functioned not only as material bonding (the mining, exploitation, transportation, exchange to the processing and distribution of jade minerals), but also spiritual bonding (the cross-region spreading and unification of jade's mythological concept) to the economic and social integration of the Central Plains and the neighboring tribes. The long-term interaction of material and spiritual bonding contributes the core values of Chinese civilization before the Bronze Age: jade as holy, treasure, and the holy article or symbol to communicate man and god. Then how these core values play in the formation of Chinese identity, what role did the jade mythology play in constructing the core values and how this role lead to Chinese historical and cultural identity will be discussed in the following.

\section{Mythological Genes of Chinese Identity}

Jade functions as the basic motive and strong bounding to the economic and social integration of the Central Plains and the neighboring tribes. In the process of centralization of integration, the mythological concept, or the shamanism of jade enjoys wide spreading popularity. Max Müller proposed that, "if we want to understand, more than just know, the ancient style of uncivilized peoples, we must try very hard to distinguish. Sometimes, a log or a stone is worshiped, because it belonged to an obsolete altar, or a trial place in the ancient; sometimes it represented a spot where a great battle or murder happened; sometimes it belonged to certain king's tomb; sometimes it guarded the holy border of a race or clan. Some stones can be used to make weapons, some to sharpen weapons; and some are jade stones discovered in Swiss Lake which are treasure imported from a faraway place and handed down from ancient times and; some are meteorites fallen from the sky. For various reasons, the ancient people, even modern people, treat them with respect. And can we simply call them as fetishes?" (Max Müller, 1989: 69) Müller holds the substantial researchers provides a powerful approach to penetrate the blurring phenomena and identify the underlying conceptual motive which deified these fetishes.

Through the analysis of the former jade myths, we can grasp the ideological meaning of mythology. According to Streng, mythology is "the story about the supernatural beings. It, by means of symbolic creativity, brings order to human's existence and meaningfulness to the world. Mythology has another concept of being the supreme values for people who live in orders and regulations."(J.Streng, 1989: 69) What Streng stressed is, the ideology of mythology creates order or restores stability with supreme values among certain cultural groups, and subconsciously dominates the conceptual and behavioral choices of every member within this cultural community., The ideology of mythology is 
one of the core values people are looking for and rely on, and is the cultural gene that identifies and determines the specific coding system of the culture. Similar to the myths of gold, which function as the stereotype codes in the construction of the value hierarchy of western civilization, myths of jades serves as the stereotype code in constructing the value hierarchy of Chinese civilization. Through the comparison between the gold (gold bough or gold lamb hair) search in Greek mythology and the jade search in Chinese mythology (King Mu's long journey to the Yellow Emperor Palace, the Queen Mother of the West's jade lake) the peace jade wanted by King Zhao of Qin; the jade imperial seal passed from dynasty to dynasty), we can aware the different core values and mode of thoughts between the western and the Chinese mythologies at the initial stage.

According to Peter Berger, "The sociology of knowledge must not only deal with the empirical knowledge, but also the various processes during which all these knowledge was constructed into the reality". (Berger, 2009: 3).Streng suggests the research on mythology's function in the realityconstruction and life-reformation, should focus on production mode of mythology and rites, as the sign symbols, which accomplished essential spiritual transformation by way of holy symbols. The representation can be generalized with a five-stage schema: Firstly, the imperfection of human's circumstances: the imperfection of the secular world. Secondly, the supreme entity or the holy kingdom: the source of orders and internal values. Thirdly, essential spiritual transformation: the holy power was represented in the existences by way of the mythological discourses or actions, which could be practiced by the priests or witches and became the widely-accepted routine of daily lives. Fourthly, individual representation: by worshiping ceremonies or rites, to gain the meaning of life and the strength from the holy kingdom. Fifthly, social representation: individual lives were integrated into a whole social entity, through regularly repeating the holy discourses and postures and living the ideal life described by holy narratives or moral lessons. (J. Streng, 1989: 67)

The ideology of jade mythology includes concepts and notions that regarding jade as god, as the symbol of celestial bodies, as the symbol of immortality etc., sorcery rites and practices like worshipping gods or the ancestors with jades, legends and stories which value jades, ideal morals (the virtues of jade) and teaching or learning method (cutting, grinding, carving and polishing) extended from jades, the social customs of wearing jades (a gentleman must wear jade), linguistic customs formed from the supreme values of jade, naming people with jade or jade articles (Jade Girl, Jade Lake), various idioms and proverbs with jade myths as the core values etc. In the long term interaction of multi cultures, these jade-related ideology predominated in the Central Plains, became the identity shared by many kingdoms and tribes surrounding the Central Plains. (Yang Jianfang, 2008). Jade contributes to the construction of the fundamental element of Chinese cultural identity, and functions as the sign of bonding identity several thousand years prior to the First Emperor of Qin's unifying China. It can be identified and proven by the prosperity of jade production of Dawenkou Culture in the east, Qijia Culture in the west, Hongshan Culture in the north, Lingjiatan Culure in the south, and Liangzhe Culture, Shijiahe Culture, and the commonality of jade articles, such as Huang (semi-circular jades), Bi (round flat pieces of jade with a hole in its center, which was used for ceremonial purposes in ancient China), Qiong (fine jades) etc.

After the Shang and Zhou dynasties, the ideology of civilized nation diverts from the initial stage of the oral mythology, since the media of mythology transforms from oral to the written characters. Thanks to the written characters, mythological narratives and expressions become accessible to an ever-increasing number of literals and function as the bondage to unify the cultures of different regions. In Shuo Wen Jie Zi, 124 Chinese characters have something to do with the jade, since most of them are the technical name of jades from places of multi-directions. This conforms to the vast geographic distribution (140 mountains producing jades) of jades as recorded in The Classic of Mountains and Seas. Inspired by Shuo Wen Jie Zi's high emphasis of jade characters, the Volume 30. Of the new character book, which was written by Guo Yewang of the Liang dynasty of Nanchao period, was entitled as Yu Pian (Jade Characters). The later generations followed their steps, even using "Yu Pian" to refer to Chinese characters in a general sense. For example, in the poem Old Residence of Princess Shengping, Luo Yin of the Tang dynasty said, "An immortal rode a Feng (phoenix, a holy and supernatural bird in Chinese mythology, a symbol of noble females, especially the empress, princess, etc.) and landed here. And I just finished writing the characters (Yu Pian)". And in Volume 7 of Xixiang ji zhugongdiao, “...know all the passages... remember all characters 
(Yu Pian)". These jade-related characters in Chinese intellectual history, which displays Chinese core value system could be re-examined, re-valued and re-evaluated with the aid of rich diversity of jade articles. Only in this way, the whole network of jade rites and practices from Xia and Shang dynasties to Qin and Han dynasties could be revealed.

Ye Shuxian categories the cultural identity genes of Chinese civilization to five mythological concept, whose chronological orders are as follows: Firstly, the birth of jade mythology: represented by Xinglongwa Culture in the north and Peiligang Culture in the Central Plains. The belief that "jade is heaven" and that "jade is god" is fundamental to the creation of Chinese identity. This is the embryonic period of core values, which appeared around 8000 to 7000 years ago. The two Cultures respectively produced jade and turquoise articles. Secondly, the mythological concept of "unity of man and god" which formed on the premise of "man-and-god communication". To communicate with the heaven or god under the help of jade was the source of Chinese rites-and-music culture. It was 7000 to 6000 years ago, represented by the appearance of Huang (semi-annular jade pendant), which was one of the 6 musical instruments recorded in Rites of Zhou. Evidences can be found in Hemudu Culture, Yangshao Culture, Daxi Culture, Hongshan Culture etc. Thirdly, Totem worship which is represented by mythological animal, such as dragon, turtle, snake, frog, cicada, silk worm. It were 6000 to 5000 years ago, and was represented by Double-Dragon-Head Huang of the Hongshan Culture. Fourthly, mythological geographic concept which is characteristic of "Tian Xia (land underneath heaven)". It was 5000 to 4000 years ago. In later classic, it is described as "Yu the Great's remains" (Shu: Establishment of Politics); or "Yu the Great's land" (Classic of Peotry: Lesser Court Hymns - Xinnan Mountain), "nine-state island", "holy state" etc. In the article The Fourth Year of King Xiang's Reign of Zuo Zhuan, the writer said, "Yu the Great's remains are boundless. On the map, we see it as a nine-state island". Fifthly, mythology of holy kings or holy people which is represented by Yao, Shun and Yu the Great. It was 5000 to 4000 years ago. The predecessor was jade statue in the shape of holy man that can communicate with god or heaven. After Shang and Zhou dynasties, people re-create the ancestral mythology of five kings which began with the Yellow Emperor. Such mythology is represented by Taosi Culture and Longshan Culture. (Ye Shuxian, 2012: 23-25)

\section{CONClusion}

Though the recent archaeological discoveries of prehistoric jades are galvanizing enthusiasm in the antique archaeological and collection, those discoveries still neglected by the mainstream academic disciplinary (arts, history and philosophy, philosophy) more or less. Reflection on why Chinese core values are neglected in modern society requires an examination on the methodology of cross-culture knowledge. The fixed boundary of academic disciplinary and the dominance of western discipline schema make Chinese scholars stuck in finding the counterparts of western terms, matching Chinese philosophy with foreign categorical system, such as "ontology", "epistemology", "materialism", "idealism", while ignore to identify the underlying mythological beliefs, the cultural genes of Chinese civilization beneath the characters and writing narratives.

Chinese civilization is the one of the surviving one that has a continual history that lasts for several thousand years since the Stone Age. The reason why China could live through numerous military conflicts and political transitions and still enjoys a lasting cultural vitality is the long-established cultural identity shared by various ethnics within its administration. To exam the origin of a civilization and cultural identity, is more than making a chronological table and arranging various cultural invention in order, but also exploring the core values formed along with the birth of this civilization, especially the cultural features particular to it. Jade mythology can be the key to open how Chinese civilization came into being in its special fashion, since "mythology created the entity and gave people the power to get rid of long-lasting and slowly-changing disorders which was characteristic of fear, failure to find the original and deepest source, failure to see the values and meanings etc." (J. Streng, 1989:66)

The critical link between mythology and cultural identity lies in the special cultural factors that mold the ideology. When we explore into the genes of a culture, we can grasp the core values of a special society during the interaction between material and concept, thus exploring the identity factors that unified multi-elements. For the identity genes of Mediterranean culture, there are a series of mythological concepts originated by the gold worship, such as the gold age, the identity of god and 
gold, the gold magic weapons etc. The recent civilization origin studies is to connect the mythology of holy articles and cultural identity, and describe the constructing process of core values. Modern scholars' research on unearthed gold antiques formed a trans-national cultural identity of Mediterranean civilization. Similarly, Chinese prehistoric jade articles also formed a trans-national cultural identity of East-Asia civilization, whose body was the Chinese civilization and also developed in surrounding areas. This paper traces Chinese identity back to the profound tradition of jade mythological concepts, tries to find out the underlying genes of cultural identity in Chinese civilization, to deepen the understanding of the Chinese written characters, historical incidents, and cultural expressions, and demonstrate the necessity and capacity of inter-disciplinary interpretation, especially the probability and potentiality of mutual Interpretation between the "Great Tradition" and the "Small Tradition".

\section{REFERENCES}

[1] Archeological Institute of Chinese Academy of Social Sciences (CASS) and Chinese Archeology Center of Chinese University of Hong Kong (CUHK) Edit. Exploration of the Origin of Jade Ware [M]. Hong Kong: Chinese Archeology Center of Chinese University of Hong Kong, 2007.

[2] Berger, Peter; Luckman, Thomas. The Social Construction of Reality [M]. Trans. Wangyong. Beijing: Beijing University Press, 2009.

[3] Frazer, J. G. The Golden Bough [M]. Translated by Xu Yuxin et al. Beijing: Press of Chinese Folk Literature and Art, 1987.

[4] Frazer, J. G. The Golden Bough [M].Vol. 1. London: Macmillan, 1955.

[5] Frazer, J. G. The Belief of Immortality and the Worship of the Dead[M]. London: Macmillan, 1922.

[6] Gaskell, G. S. Dictionary of Scripture and Myth[M]. New York: Dorset Press, 1989.

[7] Hesiod. The Works and Days: the Theogony [M]. Tran. Zhang, Mingzhu. Beijing: The Commercial Press, 1991.

[8] J. Streng, Fredrick. Understanding Religious Life[M]. Trans. Jin, Ze; He Qimin. Shanghai: Shanghai People's Publishing House, 1989.

[9] Li, Jinghua. Archeology of Metal Smelting[M]. Beijing: Press of Cultural Relics, 2007.

[10] Max Müller, Friedrich. The Origin and Growth of Religion[M]. Tran. Jin, Ze. Shanghai: Shanghai People's Publishing House, 1989

[11] New Testament: Gospel of Saint John. Chapter One, Article 32-33.

[12] Shinichiro, Kurimoto. Economic Anthropology[M].. Trans. Wang, Ming, et al. Beijing: The Commercial Press, 1997.

[13] Virgil. Aeneid. Aeneid [M].Translated by Rorbert Fitzgerald. New York: Vintage Books, 1983.

[14] Weber, Max. The Methodology of the Social Sciences[M]. Trans. And Ed. A. Shills, Edward. A. Finch, Henry. Illinois: The Free Press of Glencoe, 1949.

[15] Xu, Daoyun. "Gods and Ancestors". Spirit of Jade and Soul of Nation - Collected Works from Academic Seminars on Ancient Chinese Jades and Traditional Culture[C]. Edit. Fei, Xiaotong. Beijing: Yanshan Chubanshe, 2002.

[16] Yang, Jianfang. Research on South China's Pre-historical Cultural Spreading and Influence through the Jade Articles [J].Southeast Culture, 2008 (04). Nanjing: Nanjing Museum, 2008.

[17] Ye, Shuxian. Exploring the Great Tradition of Chinese Culture [J]. Social Scientists, 2011 (11): 8-12.

[18] Ye, Shuxian. The Golden Bough and the Jade Leaf - Comparative Mythology from Chinese Perspective [M]. (Serial books of Contemporary Chinese Comparative Literature Studies) Shanghai: Fudan University, 2012.

[19] Ye, Shuxian. History of Chinese Mythology: from Chinese-Myth to Myth-China [J]. Baise Institute Journal, 2009, 22(1): 33-38.

[20] Yuan, Ke. Collation and Annotation to the Classic of Mountains and Seas [M]. Shanghai: Shanghai Publishing House of Classics, 1980.

[21] Yuan Ke. Foreword[M].//Anne Birrell. Chinese Mythology: An Introduction. Baltimore \& London: Johns llopkins University Press, 1993.

[22] Zhang, Dainian. Chinese History of Ideas[M]. Zhengzhou: Zhongzhou Guji Chubanshe, 2005. 


\section{AUTHOR'S BIOGRAPHY}

Dr. Juan Wu, a lecturer at School of Foreign Language, Beijing Institute of Technology, mainly engages in the study of English Literature and Literary Theory, Cultural Studies and Comparative Mythology. She has authored Vladimir Nabokov: "A Rigid Moralist" and numerous articles on academic journals. Recently she focuses on the Retelling of Myth in the Postmodern Sign Economy and Archetypal Criticism of Chinese Jade Mythology. 